\title{
Quem fará a nossa Perestroika? Imagens de Mikhail Gorbatchev no jornal O Globo*
}

\author{
Izabel Cristina Gomes da Costa**
}

Quem fará a nossa Perestroika? Esta surpreendente pergunta foi feita por $O$ Globo em 1988. Mais desconcertante ainda: a publicação utilizou-se das reformas na União Soviética (URSS) de Mikhail Gorbatchev para defender uma visão de mundo e um projeto político para o Brasil. O presente artigo identifica as estratégias elaboradas pelo jornal na construção das imagens do dirigente soviético. Delineando quatro momentos, elas revelaram as mudanças no seu perfil durante a crise do socialismo real.

Palavras-chave: O Globo - Mikhail Gorbatchev - Brasil

Who will make our Perestroika? Images of Mikhail Gorbatchev in the newspaper O Globo

This surprising question was published in 1988 in the newspaper $O$ Globo. Another astonishing fact was that the publication used the changes then being undertaken in the USSR and the figure of Mikhail Gorbatchev to propose a political project for Brazil. The present article identifies some strategies used by the newspaper to build images of Mikhail Gorabtchev in four moments which reveal his nature during the crises of "existing socialism".

Keywords: O Globo - Mikhail Gorbatchev - Brazil

* Artigo recebido em março de 2007 e aprovado para publicação em junho de 2007. Ele foi originado da dissertação de mestrado da autora, Izabel Cristina Gomes da Costa, Troca de sinais: uma análise histórica da leitura do jornal O Globo sobre as reformas na União Soviética (1985-1991), Niterói, dissertação de mestrado, Programa de Pós-graduação em História da UFF, março de 2000.

** Doutoranda do Programa de Pós-Graduação em História da Universidade Federal Fluminense, professora da Universidade Cândido Mendes e professora de História da rede pública. E-mail: izacris68@oi.com.br. 
Qui fera notre Perestroika? Les Images de Mikhail Gorbatchev dans le journal O Globo

Cette étonnante demande a été élaborée par le journal O Globo en 1988. Plus embarrassant encore : la publication a mobilisé les reformes en URSS et la figure du leader communiste Mikhail Gorbatchev pour défendre une vision de monde et un projet politique pour le Brésil. Cet article identifie quelques stratégies employées par le journal afin de construire les images du dirigeant soviétique à travers de quatre moments qui révèlent les mutations de son profil pendant la crise du socialisme réel.

Mots-clés: O Globo - Mikhail Gorbatchev - Brésil

A investigação sobre a produção dos discursos e das representações sociais vem adquirindo bastante proeminência nas pesquisas históricas contemporâneas. Importantes estudos, como os de Bronislaw Baczo, ${ }^{1}$ indicam os imaginários sociais como um espaço estratégico de legitimação do poder, construído a partir da experiência e dos desejos dos agentes sociais.

$\mathrm{O}$ advento das tecnologias de comunicação e a centralidade dos mass media no século XX selaram uma complexa relação entre informação e imaginação. Nesta perspectiva, a mídia também se configura como um lugar de fabricação dos imaginários sociais. Por isso, a necessidade de compreender como se opera o poder nas sociedades contemporâneas torna-se central. Baseando-nos em Pierre Bourdieu, o campo da produção do poder simbólico "é um microcosmos da luta simbólica entre as classes" que lutam para impor uma determinada visão de mundo. ${ }^{2}$

Quem fará a nossa Perestroika $?^{3}$ Esta surpreendente pergunta foi feita pelo editorial do jornal O Globo em 1988. Mais desconcertante ainda: a publicação utilizou-se amplamente das reformas realizadas na URSS e da figura de seu líder máximo, Mikhail Gorbatchev, para defender uma nova hegemonia para o Brasil nos anos 1980.

Que país era esse? Em pleno processo da transição conservadora, após anos de regime de ditadura militar, as forças políticas brasileiras deparavam-se com a necessidade de estruturar um novo projeto político, econômico e social para a nação. A chamada década perdida combinava uma intensa reorganização

\footnotetext{
${ }^{1}$ Bronislaw Baczo, "Imaginação social”, Enciclopédia Einaudi, vol. 5, Porto, 1985.

${ }^{2}$ Pierre Bourdieu, O poder simbólico. 2. ed., Rio de Janeiro, Bertrand Brasil, 1998.

${ }^{3}$ O Globo, 10/03/1988, p. 4.
} 
e movimentação da sociedade civil com uma profunda crise e fragmentação das classes dominantes brasileiras. A definição de uma visão de mundo para o Brasil operou-se exatamente no momento em que os acontecimentos na URSS aprofundavam o colapso do modelo soviético, enfraquecendo a perspectiva socialista enquanto uma utopia possível de sociedade no final do século XX.

Neste quadro, a inserção de $O$ Globo no debate nacional adquiriu uma importância fundamental. O periódico apresentava um projeto político consoante ao modelo econômico preconizado pelos organismos internacionais que ainda não havia hegemonizado o conjunto das classes dominantes no país.

O conceito de polifonia de Mikhail Bakhtin ${ }^{4}$ identifica que qualquer discurso está sempre impregnado por uma multiplicidade de vozes de outros discursos, em constante interação. Procuramos encontrar as vozes com as quais $O$ Globo dialogava sobre os destinos da nação. Sem dúvida, os confrontos fundamentais foram travados com as esquerdas. Nestes embates, os seus editoriais adotaram o processo de reformas na URSS como a principal referência, transformado-o numa espécie de paradigma para o caráter das mudanças que deveriam acontecer no país.

Certamente, O Globo, árduo defensor do sistema capitalista, não se bandeara para o campo socialista. Na sua leitura, a utilização da perestroika como um exemplo para o Brasil apontava a natureza das reformas na URSS, que se baseava em diversos valores preconizados pela publicação: a economia de mercado, as privatizações, o fim dos monopólios e a abertura para a entrada de tecnologia e de capital estrangeiros. Enfim, as transformações soviéticas atestavam a irresistibilidade do capitalismo diante do fracasso do socialismo real.

A leitura do jornal teceu uma série de comparações entre os processos vividos pelo Brasil e pela URSS. Comentando a viagem do presidente José Sarney àquele país, o editorial estabeleceu a seguinte simetria: as duas nações, cada qual a seu modo, viviam um processo de abertura. Contudo, as diferenças eram enormes. $\mathrm{E}$ as mais importantes estavam contidas no caráter das mudanças efetivadas em cada uma das regiões:

Na União Soviética, há o esforço para sacudir uma sociedade sepultada na apatia por décadas de dirigismo econômico, de preconceito ideológico contra a iniciativa privada e por uma produção desenvolvida à revelia do mercado; enquanto no Brasil, a sociedade que com tanta espontaneidade respondeu à abertura política está sendo ludibriada por um estatismo de má-fé nacionalista

${ }^{4}$ Robert Stam, Bakhtin: da teoria literária à cultura de massa, São Paulo, Ática, 1992. 
e por um pretenso progressismo, de interesse apenas de uma bem estabelecida nomenklatura.5

Quem ludibriava a sociedade brasileira, colocando-a na contracorrente da história? As esquerdas estatizantes defendiam os pressupostos que o socialismo soviético estava sepultando. Comportavam-se como os burocratas do PCUS, protegendo os interesses de um pequeno grupo. Assim, a burocracia no Brasil era constituída pela nomenklatura do movimento organizado dos trabalhadores, como o funcionalismo público, empunhando as suas bandeiras corporativistas.

A discussão sobre as privatizações das estatais brasileiras também girou em torno do exemplo dado pela URSS. Em mais uma Mensagem aos arcaicos, ${ }^{6}$ as esquerdas eram classificadas como uma petrificação ideológica, lançando mão de arcaísmos bolorentos, como a pecha de entreguismo, para tentar impedir a venda de estatais para capitais brasileiros. Enquanto isso, a pátria do socialismo emitia sinais para todas as colorações de estatizantes dos mais variados matizes: o projeto da nova legislação soviética, em acelerado processo de elaboração, autorizava a compra de $100 \%$ das ações das estatais privatizadas pelo capital estrangeiro.

Conforme assinalava um editorial do ano de $1988^{7}$, os arcaicos brasileiros preferiam subsidiar a indolência e a ineficiência de empresas através da justificativa da finalidade social, deixando falir o próprio Estado, do que lhes impor o risco real da falência tal como procedia a URSS com as suas unidades.

A eleição presidencial de 1989, a primeira após 25 anos de interregno forçado, constituiu-se no grande momento da polarização entre as visões de mundo sobre o futuro do Brasil. Este pleito, ocorrido no calor dos acontecimentos históricos que marcaram a queda do Muro de Berlim, foi perpassado pela discussão sobre a crise do socialismo real e a viabilidade das esquerdas enquanto proponentes de um projeto alternativo para a sociedade brasileira.

O editorial de $O$ Globo, estampado na primeira página e assinado pelo próprio punho de Roberto Marinho, chamava-se - e era literalmente - uma Convocação. ${ }^{8} \mathrm{O}$ texto demonstrava a crise das classes dominantes do país, em especial dos seus mais expressivos partidos políticos, PFL e PMDB. Diante do quadro de disputas internas e de grandes ambigüidades, cada qual correndo

\footnotetext{
${ }^{5}$ O Globo, 23/10/1988, p. 4.

${ }^{6}$ O Globo, 23/06/1990, p. 4.

${ }^{7}$ O Globo, 25/09/1988, p. 4.

${ }^{8}$ O Globo, 02/04/1989, $1^{a}$ página.
} 
atrás do seu candidato ideal, a publicação enxergava o crescimento dos setores da esquerda e a ausência de qualquer perspectiva do outro lado.

$\mathrm{O}$ jornal chamava as duas agremiações à responsabilidade, pois, às vésperas das eleições, as maiorias silenciosas que os tornaram majoritários no Congresso Nacional assistiam atordoadas e constrangidas "ao espetáculo de perplexidade proporcionado pela elite política do país abrigada no PMDB e no PFL". ${ }^{9}$ Estas maiorias - que condenavam as invasões de fábricas, as greves e a empáfia da CUT a bloquear qualquer entendimento - possuíam o direito legítimo de cobrar dos principais partidos uma candidatura de consenso que fosse intérprete da sua vontade política. Mesmo sem mencionar o nome do candidato consensual, as características deixavam claro que ele era Fernando Collor de Melo:

Um candidato de renovação que não se enrede em manhas e combinações inaceitáveis. Um candidato que não fuja dos temas controversos e não faça do subterfúgio a suprema sabedoria política. Um candidato, afinal, com uma abordagem moderna e otimista dos problemas brasileiros, que devolva à Nação o direito de sonhar com o futuro. ${ }^{10}$

Dois candidatos credenciaram-se ao segundo turno: Collor e Lula. Eles representavam visões diametralmente opostas de mundo, como muito bem expressou o chargista Chico Caruso ao desenhar um abismo separando os dois postulantes à presidência da república. ${ }^{11}$ O Globo também não deixou de decodificar o fosso, utilizando-o na produção de sentidos construída para ambos.

\footnotetext{
${ }^{9}$ O Globo, 02/04/1989, $1^{\text {a }}$ página.

${ }^{10}$ Idem.

${ }^{11}$ Charge de Chico Caruso publicada pelo jornal O Globo, 05/12/1989, p. 4.
} 


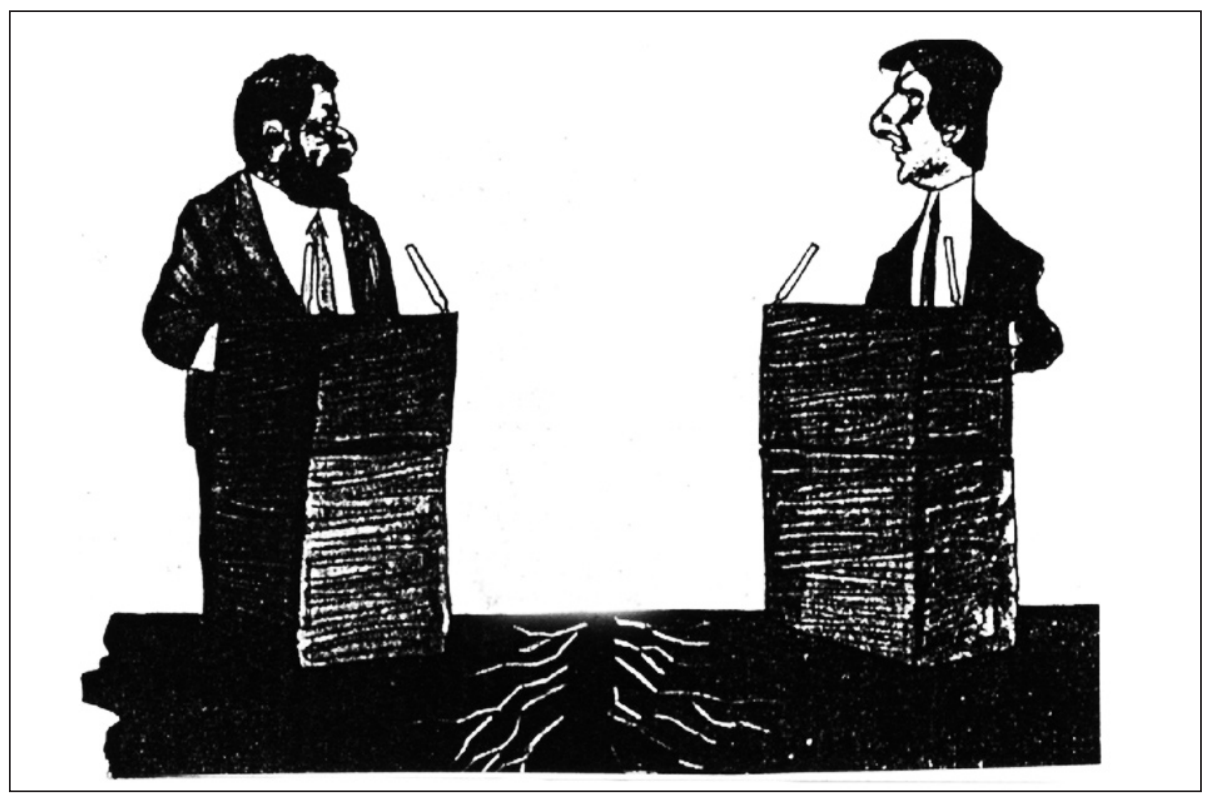

Figura 1 - O Globo, 05/12/1989, p. 4.

"Brasil, agredir o futuro". ${ }^{12} \mathrm{O}$ editorial, escrito no segundo dia de janeiro de 1990, expunha a possibilidade de uma ruptura constitucional do Brasil com a vitória de Lula. Este rompimento possuiria um caráter: implantaria o arrastão socialista no país. Na primeira página, O Globo destacava que muitos brasileiros ainda não haviam dado conta do risco por que passara a nação nas últimas eleições. Sob o pretexto de eliminar as graves injustiças sociais que atormentavam o nosso povo, o Brasil quase fora atirado para a zona de turbulência, que "iria travar o desenvolvimento, destruir as potencialidades da livre iniciativa e pôr o Brasil, neste entardecer de século, de costas para o futuro". ${ }^{3}$

Estruturando o seu discurso a partir de oposições, o periódico apontava quem eram aqueles agentes que, sobretudo nos grandes centros urbanos, haviam criado um ambiente de euforia e uma corrente de vitória, que parecia tornar inevitável o desmantelamento do regime. Eles conformavam uma frente política de marxistas, populistas trabalhistas, socialistas privilegiados, dentre outros. Juntavam-se também a eles intelectuais, artistas, estudantes, padres e burgueses. Contrárias a esta correnteza de demagogia e de promiscuidade,

${ }^{12}$ O Globo, 02/01/1990, $1^{\text {a }}$ página.

${ }^{13}$ Idem. 
erguiam-se as maiorias silenciosas, esquecidas e humilhadas: o povo humilde das grandes e pequenas cidades e do interior, os operários das fábricas de São Paulo, os trabalhadores do campo, os pequenos e médios empresários.

Os eleitores brasileiros colocaram-se diante de duas opções: "ou escolhiam o Brasil da esperança, do progresso e da modernidade, ou preferiam o Brasil da agitação e do bota-abaixo". ${ }^{14}$ Por um triz escapamos, aclamava o jornal. A população optara tornar vencedor o candidato que preconizava as mudanças sem violência e baderna. Logo, chegava a hora de implementar as reformas, unindo os brasileiros em torno de um programa de salvação nacional. Era a hora de agredir futuros para que o país não corresse mais o risco de retrocesso e abafamento da democracia.

"Quem fará a nossa perestroika? Quem nos matriculará na escola moderna de Gorbachev??". ${ }^{15}$ A pergunta de O Globo identificava a ausência de um líder que fosse capaz de inserir o Brasil na escola do presidente da URSS, conduzindo-o no rumo correto. Em consonância com a estratégia de impor como verdadeira a sua visão de mundo, o jornal também teceu várias imagens referentes à figura do dirigente máximo da perestroika, delineando quatro momentos fundamentais.

\section{Uma novidade intrigante}

Em 1985, o clima de Guerra Fria ainda prevalecia na cena mundial. O aparecimento de Mikhail Gorbatchev gerou um sentimento ambíguo de desconfiança e de surpresa. De fato, nessa época, O Globo não havia mudado a sua concepção sobre a URSS, baseada na teoria do totalitarismo: um país cinzento, uniforme, onde nada acontecia. Como explicar o surgimento de um líder com as características de Gorbatchev? O charme que estava encantando o mundo seria um predicado tardiamente descoberto pelo ocidente?

A surpresa localizava-se na sua própria imagem: ao contrário do perfil geriátrico dos dirigentes políticos que comandaram o país nos anos anteriores, o secretário-geral, recém-empossado em março de 1985, exalava um ar juvenil, dinâmico e renovado.

Outra novidade: o novo líder não possuía aversão às câmeras, luzes, microfones e gravadores. Também não era uma pessoa envolta no mistério de aparições sazonais como os seus predecessores. A mídia não fechou os

${ }^{14}$ O Globo, 02/01/1990, $1^{\text {a }}$ página.

${ }^{15}$ O Globo, 10/03/1988, p. 4. 
olhos: as imagens exploraram a descrição de um dirigente assemelhado aos líderes ocidentais. A sua estratégia ficou conhecida internacionalmente como a ofensiva de charme, um estilo que somente o ocidente poderia possuir e não um país petrificado como a URSS.

Dessa forma, apresentava-se o perfil do casal Raisa e Mikhail Gorbatchev como figuras educadas e elegantes, conforme o padrão dos dirigentes e das primeiras-damas ocidentais. Mas eles continuavam comunistas... Um acidente de percurso, segundo a declaração do jornal inglês The Sun, destacada por O Globo: "É uma pena que Raisa e Gorbachev sejam comunistas". ${ }^{16}$

Os primeiros tempos da ascensão do líder foram marcados por um sentimento de novidade, cujos objetivos intrigavam a análise dos observadores da imprensa internacional. Até o ano de 1987, o jornal veiculava matérias que enfatizavam a desconfiança e o ceticismo em relação às reformas naquele país. Uma das comparações mais emblemáticas equiparava o dirigente soviético ao czar Pedro, o Grande, reformador e modernizador da Rússia czarista, sem, contudo, alterar o regime absolutista. Um nó precisava ser desatado pela imprensa: será que tais mudanças poderiam revigorar o socialismo em escala internacional?

Mesmo divulgando visões mais cautelosas, a percepção do periódico comportou-se de forma mais fluida, otimista e simpática em relação ao perfil do secretário-geral. No começo do ano de 1987, ele deixava de ser uma novidade: adquiria a condição de inovador. Detentor de uma autodeterminação que somente os grandes líderes possuíam, rompia com "a monotonia ufanista de seus antecessores". Colocava-se como "crítico mordaz do desempenho econômico do seu país". ${ }^{17}$

Portanto, o líder soviético era apresentado como um reformador e modernizador em contraposição à rigidez burocrática e ineficiente, ao centralismo administrativo e ao conformismo irresponsável do conservadorismo. A cautela da publicação quanto ao fôlego das reformas localizava-se nas limitações impostas a ele pelo próprio sistema, impermeável à evolução.

\section{Uma novidade fascinante. OHomem do Ano}

Mikhail Gorbatchev começava o ano de 1988 como a figura política que roubara a cena no campo internacional, eleito $O$ Homem do Ano pela revista

${ }^{16}$ O Globo, 29/03/1985, p. 30.

${ }^{17}$ O Globo, 30/01/1987, p. 4. 
norte-americana Time ${ }^{18}$ No jornal O Globo, este segundo momento representou a consolidação da sua imagem positiva. A Opção Zero, uma intensa propaganda pelo desarmamento nuclear, confirmava-o como um líder que preconizava a paz mundial, a coexistência pacífica e a interdependência entre os povos.

O periódico indicava que o caminho trilhado por Gorbatchev deixava de ser uma opção para se transformar num paradigma. Esta via parecia fecunda: o dirigente do Kremlin apostava numa proposta mais aberta, ágil e versátil. Todavia, mesmo vestido com um novo figurino institucional, ele não poderia abdicar do seu controle sobre o PCUS se quisesse levar adiante a perestroika.

O discurso de Gorbatchev ainda reafirmava o compromisso com o retorno do socialismo às suas fontes genuínas. $\mathrm{O}$ periódico, todavia, explorava crescentemente o perfil de uma liderança disposta a combater as degenerações do sistema por meio dos instrumentos da economia de mercado, da abertura do país à tecnologia e ao capital externo, assim como a adoção da livre concorrência nas empresas estatais.

A primeira ilustração da série ${ }^{19}$ sintetiza alguns aspectos importantes sobre os dois primeiros momentos da imagem de Mikhail Gorbatchev. A charge constituiu-se numa expressão emblemática do papel central exercido por ele na conjuntura mundial. Um novo sentido fora produzido para o mais importante símbolo do comunismo - a foice e o martelo -, substituindo o último pelo microfone. A opinião pública identificaria, então, a sua principal arma. A força desta representação reflete a consolidação da figura do presidente da URSS, demonstrando a incidência da sua estratégia de marketing num mundo marcado pela centralidade da mídia. Sucessor de dirigentes doentes, herméticos e sem o carisma dos grandes líderes, ele confirmou o seu prestígio internacional através da palavra.

${ }^{18}$ Veja, ano 20, 06/01/1988.

${ }^{19}$ Charge de Chico Caruso publicada pelo jornal O Globo, 09/12/1988, p. 4 


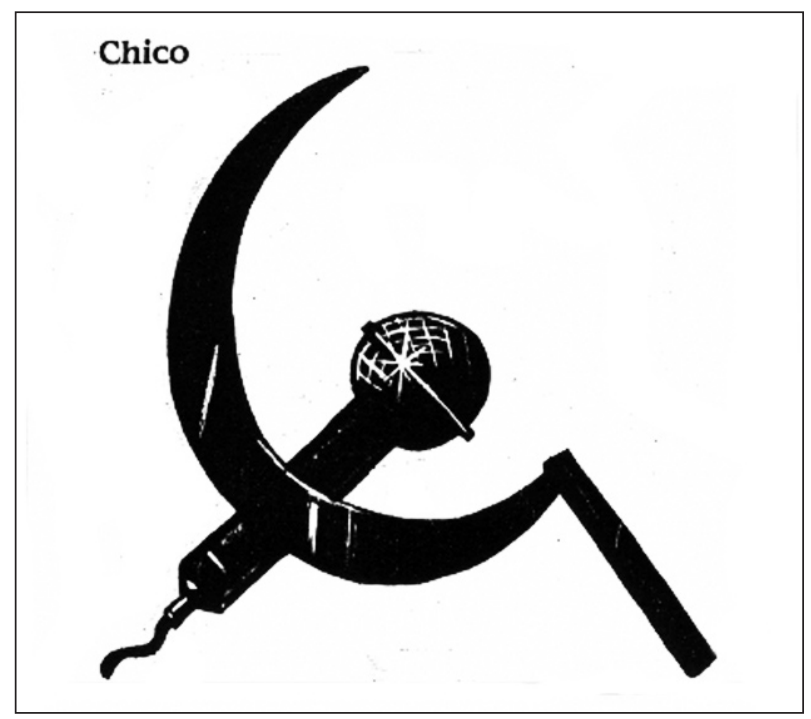

Figura 2 - O Globo, 09/12/1988, p. 4.

A primeira mancha na imagem de Mikhail Gorbatchev apareceu como o resultado da política repressiva contra as reivindicações da República da Armênia, no início de 1988. Apresentada como um "embaçamento da Glasnost e um espasmo da Perestroika", o episódio colocava-o diante da seguinte opção: "o modelo de democracia de que reclama a originalidade socialista (ou) alguma forma de reedição do estalinismo". ${ }^{20}$

Gorbatchev: de lider inconteste das reformas a homem de centro. A crise na URSS e o surgimento da alternativa Boris Yeltsin

O ano de 1989 marcou o colapso do socialismo real no leste europeu e o aprofundamento da crise na URSS, especialmente no terreno das lutas nacionalistas nas repúblicas daquele país. O jornal operou mudanças significativas no perfil de Gorbatchev, influenciadas por estes acontecimentos e acentuadas no ano de 1990. A sua imagem adquiriu uma conotação crescentemente ambígua com o acirramento da instabilidade interna. Para que a perestroika continuasse a ter credibilidade, o aprofundamento das reformas tornava-se uma necessidade vital. Num partido dominado pelos conservadores, os obstáculos

${ }^{20}$ O Globo, 08/04/1988, p. 4 
eram inúmeros, mas ele "não poderia continuar indefinidamente na posição ambígua de um inconformista bem instalado no poder". ${ }^{21}$ Mesmo assim, a publicação ainda avaliava como necessária a sua atitude, tentando equilibrarse entre a confiança do partido e a do Congresso.

No transcorrer de 1990, os antigos países comunistas do leste europeu adotaram a economia de mercado. Na URSS prevalecia a hesitação do presidente soviético quanto ao aprofundamento das mesmas medidas, realizadas naquelas nações sob a sua inspiração. Segundo a visão do periódico, a sua vacilação colocava-o na condição de "cúmplice do passado". O estalinismo deixava de ser o bode expiatório perfeito da degeneração do sistema e da lentidão da perestroika. Portanto, ele encontrava-se na berlinda.

O Globo expressava prudência, mas ainda jogava as suas fichas em Gorbatchev: não vislumbrava outra liderança capaz de substituí-lo, levando adiante o seu ousado projeto e os avanços obtidos com a sua ascensão na URSS. Mesmo com a ausência de tais líderes, o periódico assinalava a importante eleição de Boris Yeltsin, em maio de 1990. O presidente do Soviete Supremo da Federação Russa passava a ocupar um lugar crucial na luta política desenvolvida no país, como a principal liderança dos reformistas ultra-radicais, à esquerda de Mikhail Gorbatchev.

As charges também expressaram o acirramento da crise na URSS. Entre os dias 20 e 23 de maio de 1990, as ilustrações demonstravam a delicada situação do dirigente soviético: aflito, ele procurava emprego nos classificados de O Globo. ${ }^{22}$ Como detalhe mais original, a articulação entre as crises brasileira e soviética. Vários personagens tupiniquins também se encontravam numa posição adversa na turbulência nacional: ao lado de Gorbatchev, a ministra da economia, Zélia Cardoso de Melo, e o técnico da seleção do Brasil, Sebastião Lazaroni, acompanhando a leitura dos classificados em busca de novas perspectivas empregatícias. Na charge do outro dia, novos personagens adentravam a cena: o ministro da justiça, Bernardo Cabral, pedia licença para folhear o periódico, juntamente com o presidente do Banco Central, Ibrahim Éris. ${ }^{23}$

\footnotetext{
${ }^{21}$ O Globo, 30/05/1989, p. 4.

${ }^{22}$ Charge de Chico Caruso publicada pelo jornal O Globo, 20/05/1990, p. 4.

${ }^{23}$ Charge de Chico Caruso publicada pelo jornal O Globo, 23/05/1990, p. 4.
} 


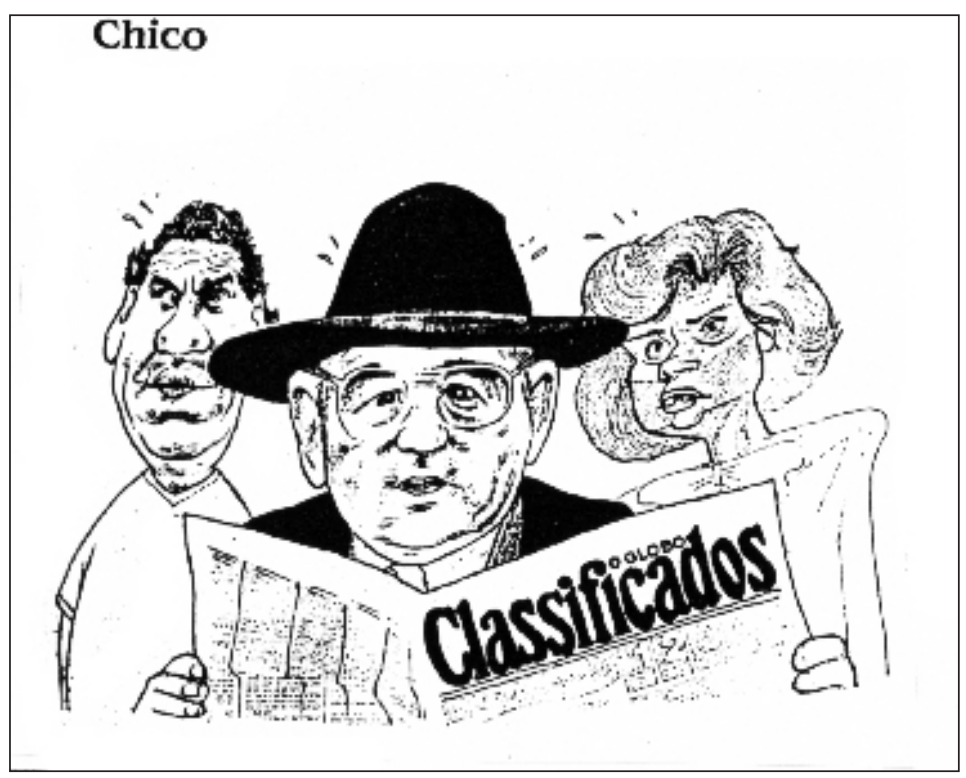

Figura 3 - O Globo, 20/05/1990, p. 4.

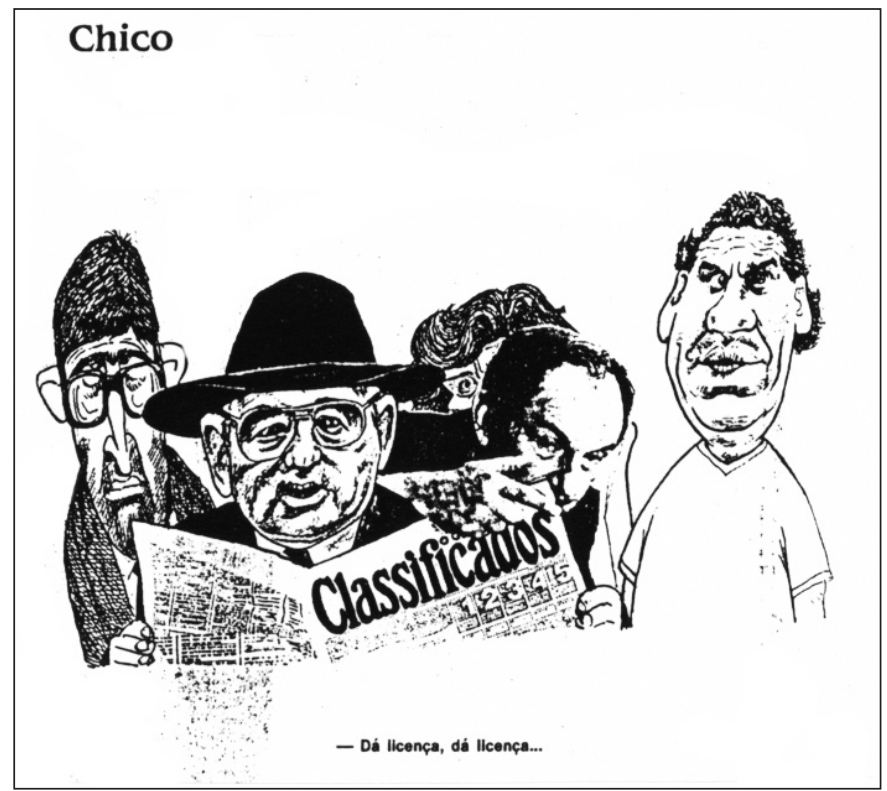

Figura 4 -O Globo, 23/05/1990, p. 4. 
A renúncia teatral do chanceler Eduard Shevardnadze, um dos principais expoentes da perestroika, a brutal repressão à rebelião nacionalista na Lituânia, a proibição da passeata do movimento Rússia Democrática, liderada por Yeltsin: estes três episódios modificaram definitivamente o perfil de Mikhail Gorbatchev em O Globo.

De líder inconteste dos reformistas, dono de um grande poder de persuasão, ele assumia uma imagem de homem de centro. Equilibrava-se perigosamente entre os ultra-reformistas e os conservadores. Cada vez mais, concentrava grande parcela de poder em suas mãos, empregando a força para conter as agitações. Apoiava-se, assim, nos pilares conservadores: o exército, o próprio partido e a polícia secreta.

No começo de 1991, a charge ilustrava o mentor da perestroika vestido com um uniforme do Exército Vermelho e com um grande bigode negro, representando, nada mais, nada menos, do que Stalin ${ }^{24}$. Simbolicamente, a ilustração procurava destacar o retrocesso da ação ocorrida na república lituana, estabelecendo um paralelo com as ações militares da URSS em períodos anteriores, esmagando movimentos que reivindicavam autonomia e democracia. Este revés, portanto, poderia reconduzir o país aos tempos do estalinismo, destruindo o trabalho construído pela perestroika a partir de 1985.

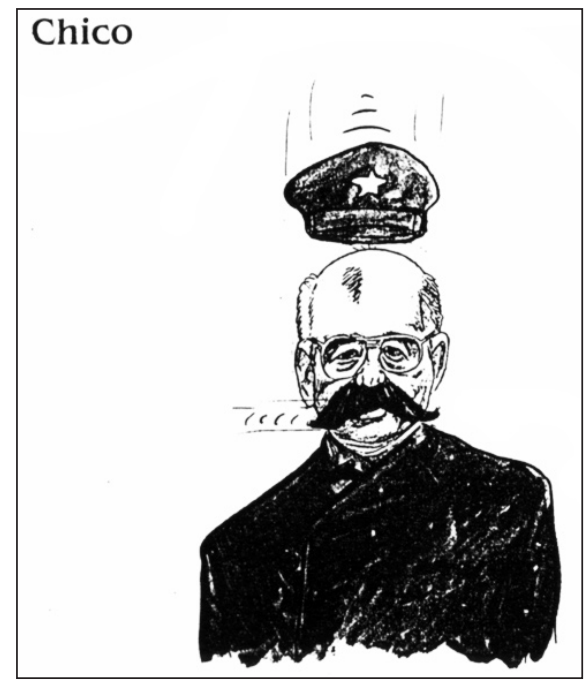

Figura 5 - O Globo, 15/01/1991, p. 6.

${ }^{24}$ Charge de Chico Caruso publicada pelo jornal O Globo, 15/01/1991, p. 6. 
No contexto de intensa crise interna e de mudanças no perfil de Mikhail Gorbatchev, o jornal apresentava Boris Yeltsin como o único adversário à sua altura, um autêntico defensor de medidas favoráveis à imediata introdução da economia de mercado e do capitalismo no país. Contrapondo-se à liderança do dirigente soviético, o presidente russo aumentava cada vez mais o seu capital político, fortalecido com a legitimidade do voto direto.

Apesar disso, Yeltsin apenas se consolidou como uma verdadeira alternativa para o futuro da URSS após o golpe de setores do PCUS, em agosto de 1991. Até a eclosão do movimento, o periódico avaliava como fundamental o papel de Gorbatchev para a contenção do caos no país. Essa visão apresentou-se de forma muito evidente no editorial "Ressurreição no Kremlin". Ele encarnava uma "moderna fênix": conseguira afastar-se da beira do abismo político para costurar um acordo com o seu arqui-rival. Assim, o dirigente ainda era muito importante "para que a sua saída (fosse) encarada simplesmente com um dar de ombros, tanto dentro como fora da União Soviética". ${ }^{25}$

Contraditoriamente à sua popularidade descendente na URSS, $O$ Globo reafirmava a atuação central de Gorbatchev na arena internacional. O encontro com o Papa João Paulo II, no final de 1989, assumiu esta dimensão. Ao contrário de líderes menores, o papel desempenhado por estes dirigentes máximos no planeta arrastava-os "para muito além do previsto e estabelecido; (levando-os) a inventar o futuro". ${ }^{26}$

A charge do mesmo dia ${ }^{27}$ assinalou o encontro que restabeleceu as relações diplomáticas entre Moscou e a Santa Sé. O menino do rio Volga surfava, ultrapassando os limites do muro que separava os líderes mundiais; ou melhor, o mundo ocidental cristão do soviético. A sua impetuosidade rompia com a rígida divisão existente entre os dois mundos, em prol do diálogo e da construção de um sistema planetário interdependente. Ele, portanto, ultrapassava as fronteiras de um dirigente delimitado territorialmente. A sua liderança possuía uma dimensão universal.

\footnotetext{
${ }^{25}$ O Globo, 26/04/1991, p. 6.

${ }^{26}$ O Globo, 02/12/1989, p. 4.

${ }^{27}$ Charge de Chico Caruso publicada pelo jornal O Globo, 02/12/1989, p. 4.
} 


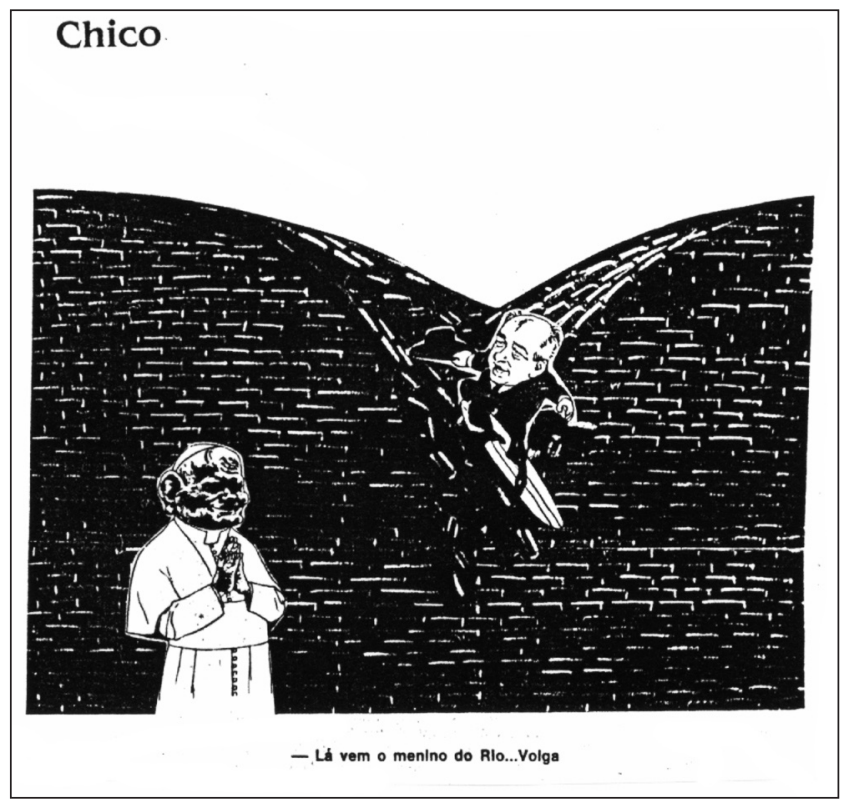

Figura 6-O Globo, 02/12/1989, p. 4.

O discurso acerca de uma nova era na conjuntura internacional também foi tema de editorial e charge em $O$ Globo. ${ }^{28}$ No momento da segunda visita do secretário-geral do PCUS aos Estados Unidos, em 1990, Mikhail Gorbatchev e George Bush, desenhados num ringue, vestidos como boxeadores, apertavam as mãos cordialmente sorridentes. As duas potências, que haviam lutado pela supremacia mundial durante anos, se reconciliavam através de seus líderes máximos. Na ilustração, eles encontravam-se em pé de igualdade, mesmo que a situação da URSS apontasse o contrário: o papel do país tornava-se secundário àquele desempenhado pela superpotência restante: os Estados Unidos.

O aprofundamento da crise na URSS e as oscilações de Mikhail Gorbatchev estremeceram o seu prestígio internacional, delineando o tratamento dado pelas principais nações desenvolvidas do planeta. Como uma figura dramática, ele fazia apelos, não menos desesperados, clamando por uma ajuda internacional que não vinha socorrer um país em dissolução. A admissão da União Soviética, com status de país observador, no GATT (Acordo Geral sobre Tarifas e Comércio) foi lida como uma etapa necessária do aprendizado. A

\footnotetext{
${ }^{28}$ Charge de Chico Caruso publicada pelo jornal O Globo, 02/06/1990, p. 4.
} 
posição de Gorbatchev era a mesma de um aluno que precisava urgentemente cumprir a tarefa de introduzir o capitalismo no país. As principais objeções ao seu ingresso naquela instituição relacionavam-se à permanência do mesmo sistema econômico, incompatível com instituições do mundo livre.

\section{A vez de Yeltsin e um lugar para Gorbatchev}

O golpe realizado por setores do PCUS, entre os dias 19 e 21 de agosto de 1991, demarcou o ocaso definitivo de Gorbatchev e a consolidação de Yeltsin como o principal líder de um país à beira do colapso. Um dia após o putsch, num longo editorial denominado, "O mundo sem Gorbatchev", $O$ Globo fazia um balanço da importância histórica do dirigente deposto e dos desdobramentos da sua prisão. Para o jornal, o libertador da Europa oriental e dos coraçôes e mentes dos soviéticos tornava-se um dos maiores estadistas do nosso século.

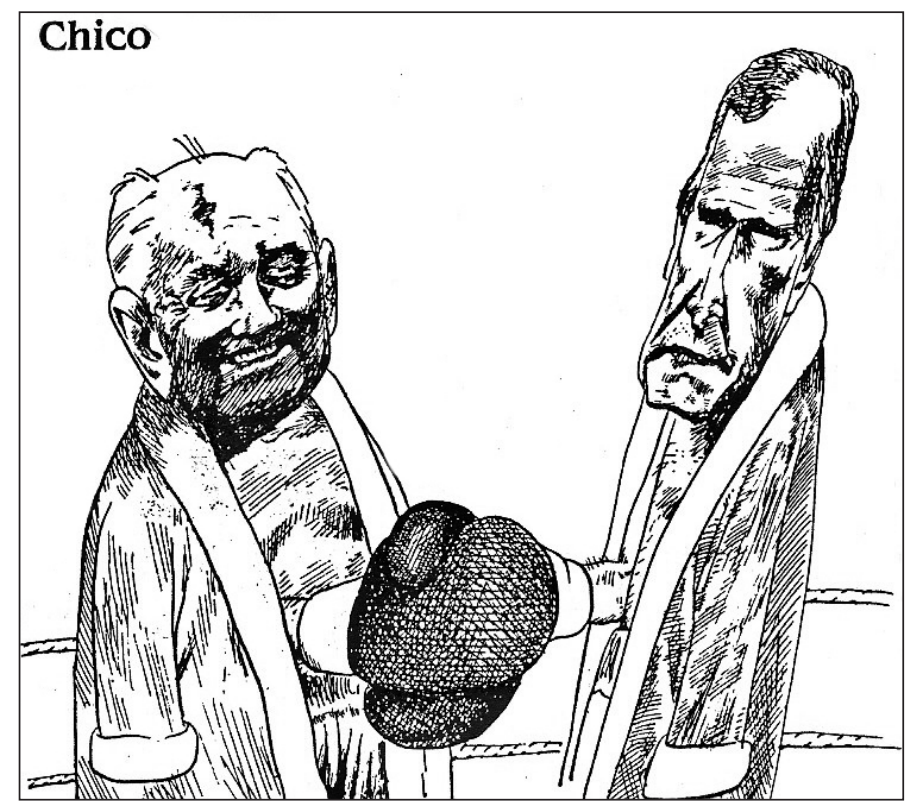

Figura 7 - O Globo, 02/06/1990, p. 4.

Mas, o seu principal adversário ascendia ao patamar de herói. Ele personificava o espírito libertário de democrata radical necessário aos novos dirigentes. Ele era o genuíno representante do povo soviético que "pela primeira vez 
na história da nação russa (declarava-se) dono do seu destino". ${ }^{29} \mathrm{O}$ futuro dos cidadãos associava-se à posição conquistada pelo presidente da Rússia durante o processo de resistência ao golpe. Os dois mais proeminentes líderes do país representavam uma outra Rússia: mais moderna, nova e também disposta a abrir-se para o mundo. Do outro lado, os golpistas de agosto tentavam manter a qualquer preço uma Rússia imemorial, estática e isolada.

Nos primeiros momentos logo após o fracasso do putsch, o jornal indicava o fortalecimento e o retorno da popularidade do dirigente soviético. Destacavase o seu heroísmo, visto que ele poderia ter decidido apoiar o movimento golpista para tentar manter-se no poder. Nas charges ilustradas entre os dias 20 e 28 de agosto de 1991, a mancha localizada na fronte de Mikhail Gorbatchev configurou-se na chave para a compreensão dos significados do golpe. Representando o mapa do país, o sinal do secretário-geral aparecia estilhaçado e o seu semblante demonstrava surpresa. ${ }^{30}$ Portanto, o putsch voltava-se contra o mesmo e a própria a URSS.

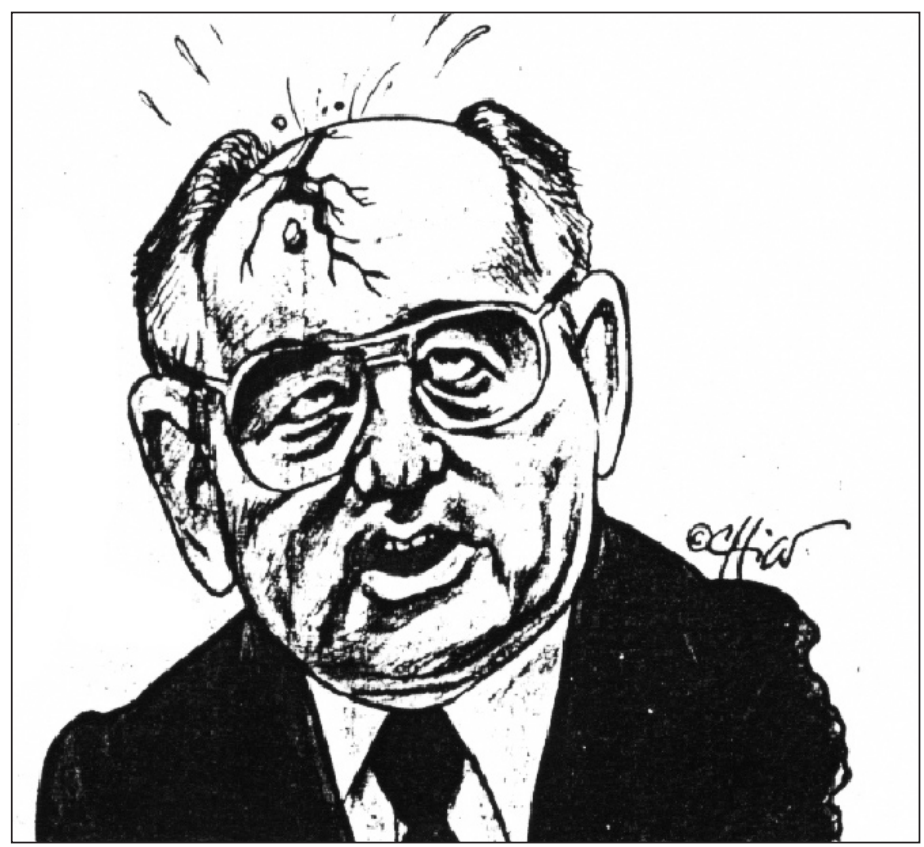

Figura 8 - O Globo, 20/08/1991, p. 6.

\footnotetext{
${ }^{29}$ O Globo, 22/08/1991, $1^{\text {a }}$ página.

${ }^{30}$ Charge de Chico Caruso publicada pelo jornal O Globo, 20/08/1991, p. 6.
} 
Na $1^{\text {a }}$ página de $O$ Globo, um outro cartum destacava o fracasso do golpe devido à mobilização popular e a atuação fundamental de Boris Yeltsin, que garantiu o retorno de Gorbatchev ao poder. O presidente da federação russa aparecia vestido como um super-herói, irrompendo da mancha frontal do dirigente soviético. ${ }^{31}$ Assim, tornava-se a encarnação legítima da perestroika e da glasnost: saía da cabeça do mentor das reformas para salvá-lo. Também representava o nascimento de uma nova Rússia, surgida definitivamente no momento do putsch. Ao contrário da primeira ilustração, o rosto de Mikhail Gorbatchev parecia aliviado.

Mesmo assim, a publicação se solidarizava com a cautela do ocidente quanto ao futuro do país sem o seu líder mais importante, aventando, por isso, a possibilidade de ele exercer um novo papel na conjuntura do país. Ele poderia ser um "fiel da balança", um "intermediário" ou um "poder moderador" para "os excessos do nacionalismo", cujo exemplo iugoslavo muito preocupava.

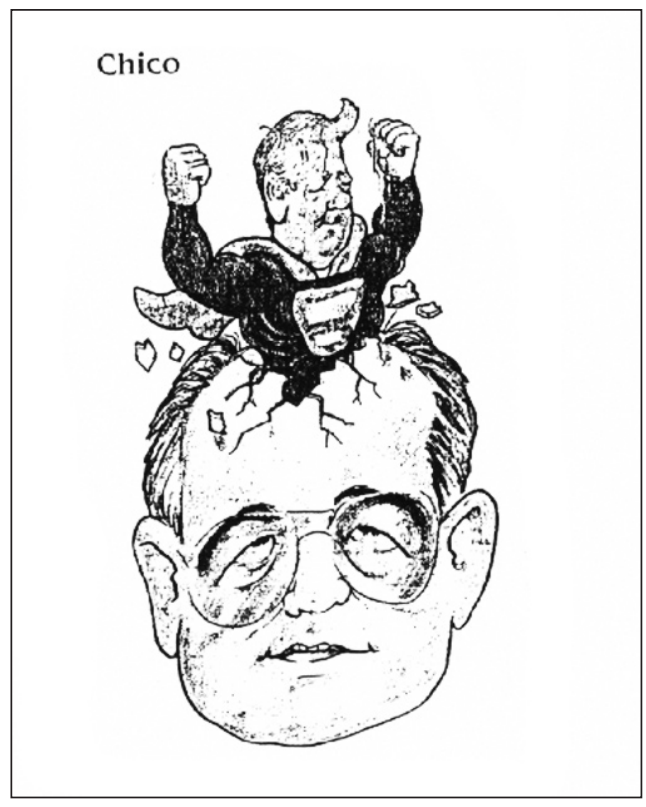

Figura 9 - O Globo, 22/08/1991, $1^{\text {a }}$ página.

O iminente fim da URSS e o esvaziamento vertiginoso da figura de Gorbatchev selaram o abandono da idéia do líder como um árbitro. Para O Globo,

${ }^{31}$ Charge de Chico Caruso publicada pelo jornal O Globo, 22/08/1991, p. 1. 
o mesmo homem que personificara a renovação agora era um "obstáculo ao progresso". As charges ilustraram a imagem do líder neste momento final. Da sua figura em sombra, ressaltava-se somente o esparadrapo sobre a mancha da sua fronte e a roupa do cativeiro na Criméia. ${ }^{32} \mathrm{O}$ curativo simbolizava o tratamento da ferida aberta pelo golpe. A sombra do secretário-geral, entretanto, refletia as interrogações quanto ao seu futuro e ao do país.

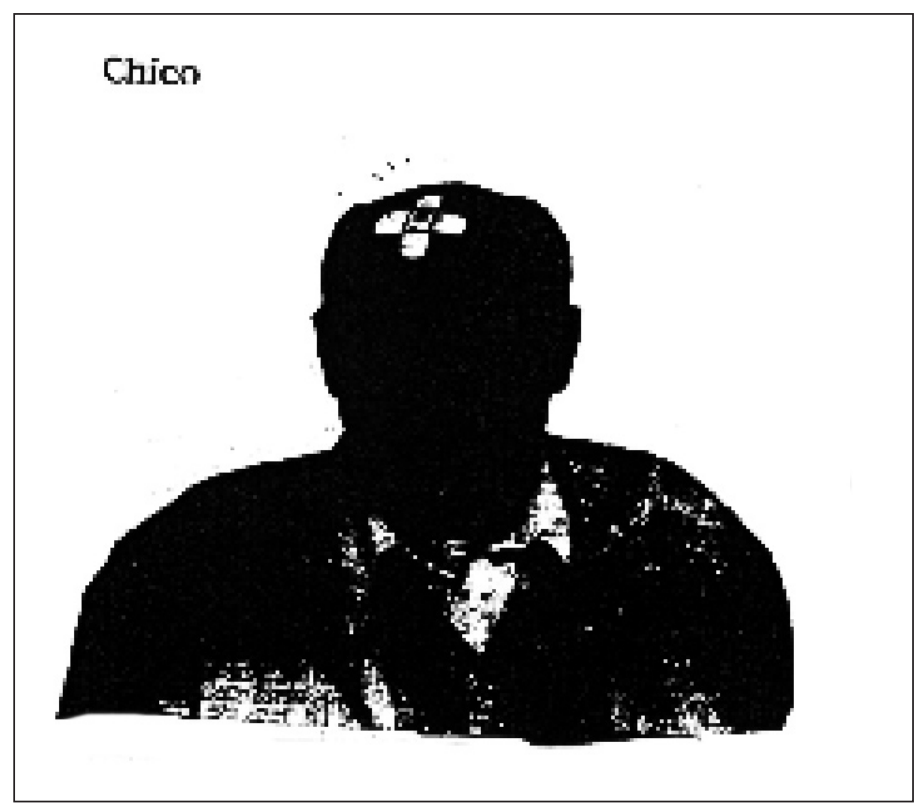

Figura 10 - O Globo, 24/08/1991, p. 6.

Na cena que antecedeu à dissolução da URSS, O Globo comparou Yeltsin e Gorbatchev a dois enxadristas que jogavam uma complicada partida: a comunidade eslava ou aquela imaginada pelo Tratado da União. Segundo o jornal, para alguns governantes europeus, como François Mitterrand, ela já havia sido decidida: a união formada pela Rússia, Bielo-Rússia, Ucrânia, além das adesões das repúblicas da Armênia e da Quirguízia, era uma realidade poderosa. Portanto, o Tratado da União, proposto por Mikhail Gorbatchev, tornava-se uma simples abstração.

\footnotetext{
${ }^{32}$ Charge de Chico Caruso publicada pelo jornal O Globo, 24/ 08/1991, p. 6.
} 
A última charge da nossa série - "Acho que isso não vai cicatrizar tão cedo..." ${ }^{3}$ - expressava a falência da URSS. A declaração de independência das repúblicas tornara inevitável a desagregação do império. Significou o caminho, a passos largos, para a extinção.

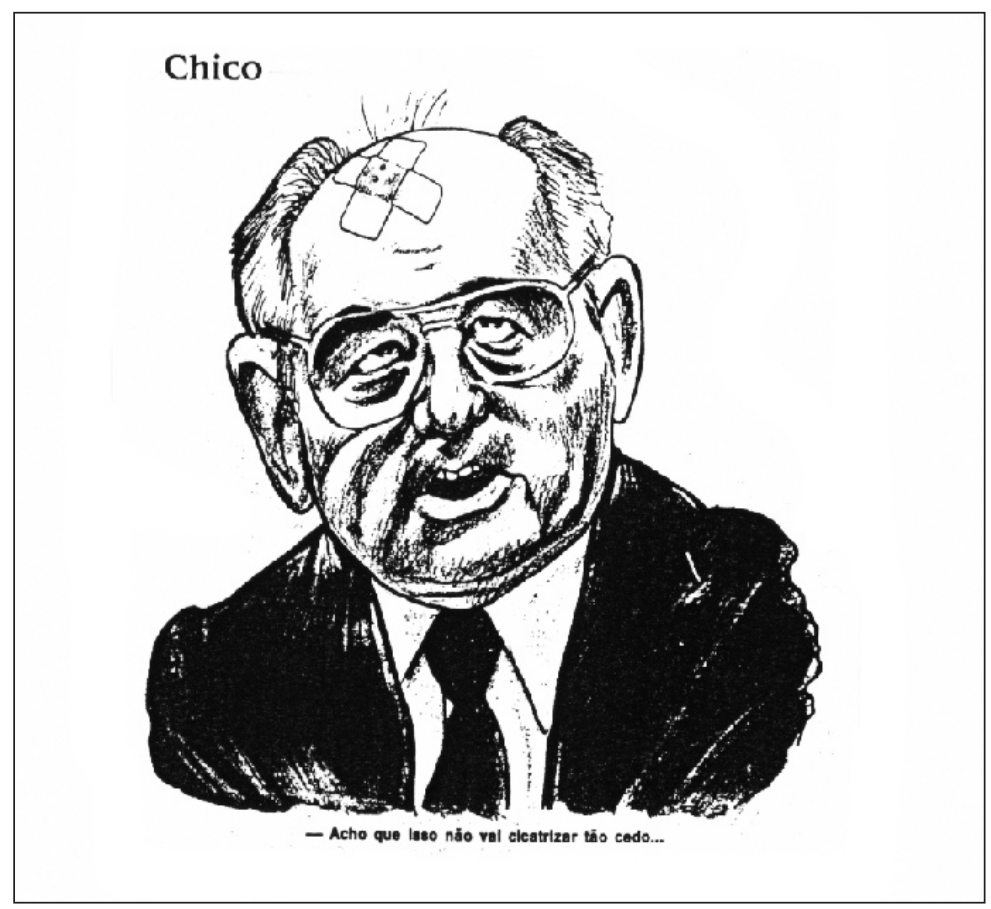

Figura 11 - O Globo, 28/08/1991, p. 6.

O mito, que a história construiu, renunciava no dia 25 de dezembro de 1991. Diferentemente de outros líderes que receberam louros e glórias póstumas, o homem não morrera, mas fora simbolicamente enterrado com as honras dos grandes estadistas. Certamente um dos mais importantes líderes do século XX, o fenômeno Gorbatchev passava para a história, vítima do processo que ele mesmo desencadeara na URSS. O desempenho pífio da sua candidatura à presidência da Rússia, no ano de 1996, desnudou a realidade crua da sentença do jornal $O$ Globo: "Assim é a História: faz os mitos para, em seguida, destruí-los". ${ }^{34}$

${ }_{33}^{3}$ Charge de Chico Caruso publicada pelo jornal O Globo, 28/08/1991, p. 6.

${ }^{34}$ O Globo, 28/08/1991, p. 6. 


\section{Gorbatchev, Perestroika e Glasnost: O Globo e a troca de sinais}

Sintonizado com a estratégia de marketing de Mikhail Gorbatchev, que explorava ao máximo a sua inserção nos meios de comunicação mundiais, $O$ Globo centrou a lógica do seu discurso na figura humana do líder soviético. Neste sentido, o jornal reproduziu uma visão tradicional na abordagem dos fatos, tratando de forma secundária as informações referentes às diversidades sociais, políticas, econômicas e culturais daquele país. A supervalorização da sua figura, não por acaso, contribuiu para o ocultamento dos processos sociais em curso, atribuindo as mudanças, principalmente no início da perestroika e da glasnost, ao gênio transformador de um dirigente de estilo ocidentalizado que expressava a superioridade deste modelo civilizatório.

A análise do jornal sobre o turbilhão que varreu o líder da URSS e o socialismo de tipo soviético da Europa, estabelecendo um novo período político no final do breve século XX, ${ }^{35}$ esteve demarcada pelos pressupostos da Teoria do Totalitarismo. O interessante estudo do cientista político Luís Fernandes, ${ }^{36}$ sobre as principais teorias marxistas e ocidentais que caracterizavam os Estados de tipo soviético, localiza a origem do vocabulário político na autodescrição elaborada pelo projeto fascista italiano nos anos 1920. Entretanto, a sua difusão deveu-se essencialmente ao contexto do pós-guerra com a emergência da guerra fria. As principais sistematizações que propagaram o conceito procederam das teses de Hannah Arendt, ampliadas por Carl Friedrich e Zbigniew Brzezinsky. Tais pressupostos apoiavam-se numa

construção taxinômica que erigia em características definidoras do totalitarismo, precisamente aqueles elementos que pudessem ser apresentados como "opostos" às instituições e práticas dos Estados liberais democráticos no Ocidente (ou, para ser mais preciso, "opostos" ao discurso liberal dominante sobre o Estado neste). ${ }^{37}$

Os Estados totalitários, portanto, demarcavam-se pelo fenômeno da entrada das massas na cena política e a conseqüente formação de regimes políticos baseados no terror total sobre indivíduos atomizados em sociedade; por uma ideologia oficial que envolvia todos os aspectos da vida humana; por

\footnotetext{
${ }^{35}$ Eric Hobsbawm, A era dos extremos. O breve século XX. 1914-1991, 2. ed., São Paulo, Cia. das Letras, 1995.

${ }^{36}$ Luís Fernandes, O enigma do socialismo real. Um balanço crítico das principais teorias marxistas e ocidentais, Rio de Janeiro, Mauad, 2000.

${ }^{37}$ Luís Fernandes, op. cit., p. 27.
} 
um partido único e um ditador; pelo monopólio dos meios de comunicação e das armas de combate, por um sistema de terror exercido através do partido e da polícia secreta e pelo controle da direção central de toda a economia.

Segundo Luís Fernandes, apesar da crise da Teoria do Totalitarismo e do seu declínio acadêmico nos anos 1960, ela continuou sendo largamente empregada pelo discurso político e jornalístico, tornando-se um paradigma natural e não problemático.

O aparecimento da perestroika e da glasnost nos anos 1980 reavivou o conceito como uma primeira interpretação para as mudanças no monolito, até então impermeável à evolução. Apesar da sua popularidade, o colapso das sociedades do campo do socialismo real colocou em cheque a sobrevivência do próprio termo como explicador das realidades destes países.

Novas leituras das ciências sociais destacavam o acriticismo da oposição criada entre o modelo do bloco socialista e o do liberal democrático, sem problematizar os impasses do próprio desenvolvimento das democracias no ocidente. Os estudos baseados na sociologia histórica e na história social, através de farta pesquisa de fontes primárias, emergiu para o plano central das análises as tensões contraditórias e as pressões sociais existentes na URSS, desmontando a visão totalitária do Estado onipresente que mobilizava e controlava os indivíduos atomizados na sociedade. O lançamento das reformas pelo principal dirigente do Estado soviético e do aparelho do PCUS, antes da eclosão de rebeliões em larga escala naquela nação, invalidou a principal idéia da tese do totalitarismo, que imputava a quebra do sistema a uma violenta intervenção externa ou a uma implosão interna.

Concebendo que a estruturação de sentidos é socialmente produzida e que “todo fenômeno social é suscetível de ser 'lido' em relação ao ideológico e ao poder", ${ }^{38}$ a leitura do jornal $O$ Globo sobre a desagregação do socialismo real apropriou-se de uma significação tradicional do binômio esquerda-direita, subvertendo tais conceitos para conseguir impor a sua definição de mundo social.

Apesar do susto inicial quanto às possibilidades de renovação do socialismo, a perestroika e a glasnost foram lidas como uma revolução recuperadora, que retomava o rumo das democracias ocidentais, corrompido em outubro de 1917. O retorno ao elo perdido acontecia através da adoção do receituário neoliberal.

${ }^{38}$ Eliseo Verón, A produção de sentido, São Paulo, Cultrix/ EDUSP, 1980. 
A glasnost expressava, no plano político, a revolução que estava se efetivando no campo econômico. Ela representava a vitória da democracia ocidental capitalista sobre o ideário de uma sociedade socialista. Segundo a publicação, a revolução em curso na URSS desautorizava os dogmas marxistas-leninistas, como a tomada de assalto do poder e o recurso à violência, confirmando a via eleitoral como o principal instrumento das transformações na sociedade contemporânea.

A luta política interna no PCUS selou, definitivamente, o processo de alteração da díade esquerda-direita. Inicialmente, Mikhail Gorbatchev e seus aliados foram apresentados ao mundo como os renovadores do socialismo. As críticas aos problemas do regime soviético alçavam-nos, perante a opinião pública mundial, à condição de alternativa à esquerda ao modelo socialista. $\mathrm{O}$ setor mais radical dos partidários da perestroika e da glasnost ficaram conhecidos como ultra-esquerdistas, sendo Boris Yeltsin o seu principal representante.

No transcorrer do processo de reformas, os editoriais de $O$ Globo clarificaram a convicção de que aquele país não estava sendo conduzido em direção a uma possível reestruturação do regime socialista. Pelo contrário, cada vez mais o caráter das propostas defendidas, por grande parte dos partidários da perestroika, incorporava o receituário neoliberal, a última moda no mundo capitalista desenvolvido.

Dessa forma, os setores denominados como esquerda reformista naquele país distanciavam-se dos pressupostos socialistas. Aqui uma pergunta impõese: se a esquerda soviética aderia ao neoliberalismo, compreendido, no restante do planeta, como um modelo econômico capitalista, onde $O$ Globo situava a direita na URSS?

Subvertendo o emprego tradicional do binômio, consolidado no século $\mathrm{XX}$, a direita era representada por todos os setores resistentes às reformas. Apesar da multiplicidade de campos de pensamento dentro e fora do PCUS, o jornal denominava os diversos grupos, portadores de críticas muitas vezes diametralmente opostas, como a burocracia do Partido Comunista. Os trabalhadores, que resistiam aos efeitos devastadores da perestroika em suas vidas, eram apresentados como negligentes, absenteístas; ou seja, cúmplices dos que arruinaram o país. A direita na URSS era composta por aqueles que pretendiam manter os seus privilégios e monopólios consolidados em décadas de regime. 
As comparações entre o processo de desagregação do socialismo soviético e a Revolução Francesa de 1789 tornaram-se muito comuns nos editoriais da publicação. O comunismo assumia o posto de Ancien Régime. Todavia, a velha ordem não estava representada pela nobreza, mas pelos burocratas comunistas que se apegavam aos mesmos privilégios dos nobres da França, e que lutavam pela conservação do status quo estabelecido com a revolução russa de outubro de 1917. Logo, concluía-se que o embate travado na pátria do socialismo equiparava-se àquele realizado em 1789: lutava-se pela instalação de um sistema baseado nos valores da democracia liberal, do liberalismo econômico e na igualdade de oportunidades contra os privilégios da burocracia.

Os partidários do projeto socialista, dentro e fora da URSS, antigos representantes, por excelência, do campo de esquerda, tornavam-se tão-somente os arautos dos dogmas do marxismo-leninismo. Eles eram os herdeiros do entulho. Por isso, encontravam-se na contracorrente dos acontecimentos, que declaravam a falência do socialismo como um projeto possível de sociedade.

A díade estava definitivamente alterada. Os socialistas não mais representavam as idéias de progresso, de mudança e de reformas, visto que defendiam a conservação de um regime retrógrado e fracassado. Encontrava-se também desfigurada a sua principal característica, a defesa do igualitarismo, pois, na prática, eles alimentavam a manutenção de privilégios corporativos e monopólios, cristalizando a desigualdade na sociedade.

Os defensores da modernidade neoliberal encarnavam um nítido perfil: lutavam pelo fim de tudo aquilo que ruíra com o Muro de Berlim, em 1989: o estatismo, o isolamento econômico, os monopólios, o protecionismo, dentre outros totens da ideologia comunista. Os novos reformistas do planeta apropriaram-se da imagem das reformas e da defesa da igualdade jurídica. Adotaram uma simbologia liberal, herdada da era das revoluções burguesas, apresentando-se como adversários dos privilégios e das corporações em defesa das máximas consagradas pelo liberalismo.

Portanto, as mudanças a serem realizadas em escala global possuíam um nome: o livre mercado da globalização mundial, irresistível a todos e a tudo. O jornal consagrava o triunfo do neoliberalismo, que declarava o sistema capitalista como vencedor e único caminho a ser trilhado.

Em síntese, o processo ocorrido na URSS atestava o malogro da maior de todas as utopias político-sociais. As reformas econômicas e a abertura do regime comunista desnudaram todas as mazelas, inerentes à gênese teórica do 
socialismo, conforme a leitura do periódico. Seguindo a avaliação de muitos soviéticos, como o historiador russo Iuri Afanassiev, e da grande imprensa internacional, a resistência ao golpe de agosto de 1991 recuperava o legado da revolução democrático-burguesa de fevereiro de 1917, abortada em outubro, desviando a Rússia do seu verdadeiro caminho por mais de setenta anos.

O Globo captou as mudanças avassaladoras, de dimensão planetária, e traduziu-as para o Brasil. No país, a ofensiva, verificada no cenário internacional, iniciou-se, de maneira mais incisiva, a partir de $1988 .{ }^{39}$ Período-chave para a sua história recente, o ano da Constituinte configurou-se num momento de disputa entre as várias visões que projetavam caminhos para a nação, após um grande período de interrupção do Estado de direito.

A troca de sinais, operada, vigorosamente, no território brasileiro, durante a segunda metade da década de 1980, tornou-se um processo vitorioso. Esta operação conseguiu difundir uma visão de mundo, consoante aos ventos internacionais, que unificou as classes dominantes do país e posicionou as esquerdas numa situação de defesa e de resistência. No âmbito da sociedade, ela logrou hegemonizar a agenda nacional, colocando na ordem do dia temas como as privatizações das estatais, a diminuição do Estado e a abertura do país ao capital externo.

A alteração da díade, portanto, não se constituiu somente na manipulação dos mass media e dos grupos capitalistas internacionais. Esta inversão amparou-se em bases reais: a direita soube elaborar um programa para as mudanças profundas pelas quais o mundo passava, anunciadas com as transformações ocorridas a partir da revolução científico-técnica. A dissolução de seu oponente permitiu-lhe consolidar a ofensiva mundial, enredando a sua imagem às idéias de modernização e de reformas.

As esquerdas, envolvidas com a crise do marxismo, que se desenvolveu antes mesmo do surgimento de Mikhail Gorbatchev e da perestroika, não conseguiram construir ou difundir uma visão de sociedade alternativa aos modelos capitalista e socialista de tipo soviético, que levasse em conta as profundas modificações vividas, em escala mundial, na cultura, na economia, enfim, no âmbito das relações sociais.

Contraditoriamente, a dissolução do mundo comunista na Europa e na URSS liberou os socialistas para a construção de novos significados desatrela-

\footnotetext{
${ }^{39}$ Armando Medeiros de Faria, O jornalismo econômico e a cobertura sobre a privatização (1990-1991). Dissertação de mestrado em Comunicação Social, São Paulo, Escola de Comunicação Social e Artes, Universidade de São Paulo, 1994.
} 
dos da experiência soviética, mas também deixou o seu ideário profundamente abalado. A superação da crise dos movimentos das esquerdas internacionais, portanto, está relacionada à necessidade e à sua capacidade de, nos dias atuais, reinventar a utopia socialista como uma idéia que novamente mobilize corações e mentes na construção de um projeto possível de sociedade. 